Available online on 15.3.2017 at http://ujpr.org
Universal Journal of Pharmaceutical Research
An International Peer Reviewed Journal
Open access to Pharmaceutical research

\title{
SYNTHESIS AND BIOLOGICAL EVALUATION OF NOVEL IMIDAZOLE BASED COMPOUNDS

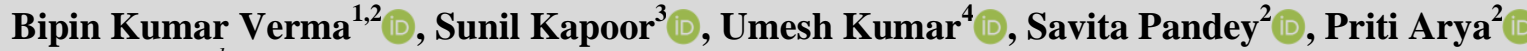 \\ ${ }^{1}$ Department of Pharmaceutical Science, Bhagwant University, Ajmer, Rajasthan, India. \\ ${ }^{2}$ Govt Polytechnic, Kashipur, U.S. Nagar, Pin Code-244713, Uttarakhand, India. \\ ${ }^{3}$ Rexcin lab. Pvt. Ltd. Baddi (H.P), India. \\ ${ }^{4}$ Department of Pharmaceutical Science, Om bioscience college, Haridwar, Roorkee-247667, Uttarakhand, India.
}

\section{ABSTRACT}

Objective: Some new imidazole derivatives (3i-xii) were synthesized as per design synthetic protocol scheme. The structures of newly prepared compounds were confirmed by modern analytical technique and elemental analysis.

Methods: All the synthetic compounds were screened for their antimicrobial activity against bacterial results showed good to remarkable activity. The MIC (minimum inhibitory concentration) values were determined by comparison to ciprofloxacin (antibacterial) and fluconazole (anti-fungal) as standard drug. Among them, compound 3iv and 3x exhibited notable antimicrobial activity. These compounds may be used as new template for the searching of potential antimicrobial agents.

Results: The purity of the compound was verified with the help of TLC (B: A, 9:1). \% age of yield was found 83\% and melting point noted 151-1520C. Compounds (3ii, 3viii and 3ix) were shown moderate activity against E. coli, S. aureus, M. luteus and K. pneumonia, whereas compounds (3iii, 3vii, 3xi and 3xii) showed mild activity against few bacterial strains $\mu \mathrm{g} / \mathrm{ml}$. The compounds of electron releasing imidazole derivatives (3ii, 3iv, 3viii, 3ix, 3x and $\mathrm{xi}$ ) presented comparatively better anti-fungal activity than the compounds of electron withdrawing imidazole derivatives (3iii, 3vii and 3xii).

Conclusion: The biological activity result revealed that all the newly synthetic compounds 3i-xii [4-(biphenyl-4-yl)-2-(substituted phenyl)-1H-imidazole] exhibited better antibacterial activity as compared to antifungal activity in compare to reference drug.

Keywords: Antibacterial activity, antifungal activity, biphenyl ethanone, imidazole.

Article Info: Received 7 January 2017; Revised 11 February; Accepted 8 March, Available online 15 March 2017

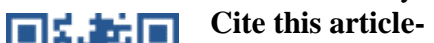

Verma BK, Kapoor S, Kumar U, Pandey S, Arya P. Synthesis and biological evaluation of novel imidazole based compounds. Universal Journal of Pharmaceutical Research 2017; 2(1):19-24.

DOI: http://doi.org/10.22270/ujpr.v2i1.R5

Address for Correspondence

Bipin Kumar Verma, ${ }^{1}$ Department of Pharmaceutical Science, Bhagwant University, Ajmer, Rajasthan, India. ${ }^{2}$ Govt Polytechnic, Kashipur, U.S. Nagar, Pin Code-244713, Uttarakhand, India, E-mail: bipinpharma@yahoo.co.in

\section{INTRODUCTION}

Nitrogen containing heterocyclic play vital role in pharmaceutical industries. The main aim of medicinal chemist in the recent times has been to develop drugs with enhanced their efficacy and duration of action and by decreasing their toxicities and side effects as well as creating new drugs by molecular modification ${ }^{1,2}$. The organic medicinal substances can be of natural or synthetic origin. The synthetic drugs are prepared by modifications of the structures of natural drugs, or by pure synthesis ${ }^{3,4}$. Over the years, innovations in new drug therapy has become, more complex, time consuming, costly, and the practicing medicinal chemists have been bombarded with surplus new methods and technologies to make the job of drug discovery more efficient ${ }^{5}$. Imidazoles are a class of five membered heterocyclic compounds having two nitrogen and three carbon atoms. Imidazole is an important group of compounds reported to have different biological activities and the present study was undertaken in order to synthesize some new derivatives of imidazole and related fused heterocyclic compounds and screen for their antimicrobial activity ${ }^{6-11}$. Among the various classes of heterocyclic compounds, imidazole is an important component of pharmacologically active compounds and a part of various available marketed drugs like Azathioprine (Leukemia), Metronidazole (Protozoal and antimicrobial activity, trichomoniasis, amoebiasis and giardiasis), dacarbazine (Hodgkin's disease), tinidazole (metronidazole), ornidazole (antiprotozoal and antibacterial activity), satranidazole (c 10213 go), (trichomoniasis and amoebiasis), cimetidtne (duodenal and gastric ulcers), carbimazole (thyroid disorders), tolazoline (vasodilator action), naphazoline (vasoconstrictor), tetrahydrozoline (vasoconstrictor) ${ }^{12-14}$. Recent studies have been revealed that the substituted imidazole derivatives attracted attention due to their 
broad spectrum of pharmacological activities such as anti-inflammatory, analgesic, antimicrobial, antiviral, antifungal, antibacterial, anti-tubercular, anti-cancer, anti-hypertensive, anti-obesity and anti-convulsant ${ }^{15,16}$. In the present studies it has been thought to synthesize newer imidazole derivatives and the structures of the synthesized compounds confirmed on the basis of their elemental analysis and modern analytical techniques such as IR, 1H-NMR and Mass spectral data results.

\section{EXPERIMENTAL PROTOCOL}

\section{General materials and instrumentations}

All the chemicals and solvent procured from E. Merck and S. D. Fine chemicals (India). Melting points were determined by open tube capillary method and are uncorrected. Thin layer chromatography (TLC) plates prepared by silica gel $G$ were used to monitor the reaction as well as to confirm the purity of the compound by using solvent systems as toluene: ethyl acetate: formic acid $(5: 4: 1)$, benzene: acetone $(9: 1)$ were used to run the TLC. The spots were visualized under iodine vapours/UV light. IR spectra were obtained on a Perkin-Elmer 1720 FT-IR spectrometer using $\mathrm{KBr}$ pellets. ${ }^{1} \mathrm{H}-\mathrm{NMR}$ spectra were recorded on DPX-300 and BRUKER-400 Ultra Shield ${ }^{\mathrm{TM}}$ NMR spectrometer, using TMS as internal standard in $\mathrm{CDCl}_{3} / \mathrm{DMSO}-d_{6}$. Microanalysis of the compounds was done on Perkin-Elmer model 240 analyzer and the values were found within $\pm 0.4 \%$ of the theoretical values. Mass spectrometry was recorded on LCMS/MS (WATERS, mass lyns version 4.1) spectrometer.

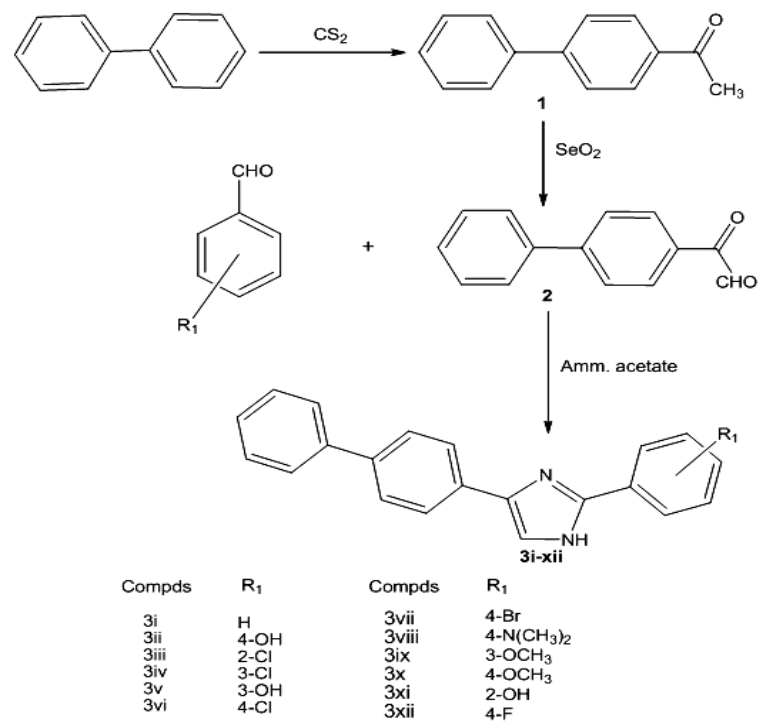

Synthesis

Figure 1: Synthetic protocol.

The compounds of the synthetic protocol scheme were obtained in the following steps

Synthesis of 1-(Biphenyl-4-yl) ethanone: The starting material biphenyl ethanone (1) was prepared by heating biphenyl with anhydrous $\mathrm{AlCl}_{3}$ in presence of $\mathrm{CS}_{2}$ and acetic anhydride. The usual work up of the reaction mixture followed by recrystallized from ethanol gave pure compound. The purity of the compound was verified with the help of TLC (B: A, 9: 1). Percentage yield was found $85 \%$ and noted $\mathrm{Mp} \cdot 158-160^{\circ} \mathrm{C}$. IR spectra are very informative and provided evidence for the formation of the expected structures.

Synthesis of 2-(Biphenyl-4-yl)-2-oxoacetaldehyde: Compound 2-(Biphenyl-4-yl)-2-oxoacetaldehyde (2) was synthesized from biphenyl ethanone (1) in presence of selenium dioxide, usual work up of the reaction mixture gave a yellow liquid which was found pure on TLC examination (TEF 5: 4: 1). The structure of compound was confirmed on the basis of spectral studies.

General procedure for synthesis of 4-(Biphenyl-4yl)-2-(substituted phenyl)-1H-imidazole (3i-xii): Biphenyl-2-oxoacetaldehyde (2) was refluxed with different aromatic aldehyde in presence of ammonium acetate and glacial acetic acid. The usual work up of the reaction mixture followed by recrystallized from acetone to get the desired products (3i-xii). The structures of compounds were confirmed on the basis of their IR and ${ }^{1} \mathrm{H}-\mathrm{NMR}$ spectral studies. The compound was found pure on TLC examination (BA 9: 1) and (TEF 5: 4: 1) and its spectral data was found satisfactory for the proposed structures.

Synthesis of 4-(biphenyl-4-yl)-2-phenyl-1Himidazole (3i): Yield: $70 \%, \mathrm{Mp}: 134-137^{\circ} \mathrm{C}, \mathrm{R}_{\mathrm{f}}=0.53$. IR $\left(\mathrm{KBr}, \mathrm{cm}^{-1}\right)$ : 3450(C-H, N-H), 3041(C-H, Ar-H), 2871 (C-H, $\left.\mathrm{CH}_{2}\right), 1595(\mathrm{C}=\mathrm{N}), 1564(\mathrm{C}=\mathrm{C}) .{ }^{1} \mathrm{H}-\mathrm{NMR}$ $\left(\mathrm{DMSO}-d_{6}, \delta, \mathrm{ppm}\right): 10.93(\mathrm{H}, \mathrm{s}, \mathrm{N}-\mathrm{H}), 6.53-8.79(\mathrm{H}$, $\mathrm{m}, \mathrm{Ar}-\mathrm{H}), 7.92(1 \mathrm{H}, \mathrm{s}, \mathrm{CH}$, imidazole). ESI-MS $(\mathrm{m} / \mathrm{z})$ : $296\left(\mathrm{M}^{+}\right)$. Anal.calcd. for $\mathrm{C}_{21} \mathrm{H}_{16} \mathrm{~N}_{2}$ : C, 65.11; H, 5.44; N, 9.45. Found: C, 75.11; H, 4.44; N, 9.51.

Synthesis of 4-(4-(biphenyl-4-yl)-1H-imidazol-2-yl) phenol (3ii): Yield: $75 \%$, Mp: $151-154^{\circ} \mathrm{C}, \mathrm{R}_{\mathrm{f}}=0.54$. IR $\left(\mathrm{KBr}, \mathrm{cm}^{-1}\right)$ : 3397(C-H, N-H), 3213(OH), 3035(C-H, $\mathrm{Ar}-\mathrm{H}), 2931\left(\mathrm{C}-\mathrm{H}, \mathrm{CH}_{2}\right), 1675(\mathrm{C}=\mathrm{N}), 1556(\mathrm{C}=\mathrm{C}) .{ }^{1} \mathrm{H}-$ NMR (DMSO- $\left.d_{6}, \delta, \mathrm{ppm}\right): 10.51(\mathrm{H}, \mathrm{s}, \mathrm{N}-\mathrm{H}), 8.01-$ $6.79(\mathrm{H}, \mathrm{m}, \mathrm{Ar}-\mathrm{H}), 9.01$ (1H, s, CH, imidazole), 9.46 $(\mathrm{H}, \mathrm{s}, \mathrm{OH})$. ESI-MS $(\mathrm{m} / \mathrm{z}): 312\left(\mathrm{M}^{+}\right)$. Anal.calcd. for $\mathrm{C}_{21} \mathrm{H}_{16} \mathrm{~N}_{2} \mathrm{O}$ : C, 80.75; H, 5.16; N, 8.97. Found: C, 80.79; H, 4.11; N, 8.95.

Synthesis of 4-(biphenyl-4-yl)-2-(3-chlorophenyl)1H-imidazole (3iv): Yield: $77 \%, \mathrm{Mp}: 148-151^{\circ} \mathrm{C}, \mathrm{R}_{\mathrm{f}}=$ 0.47. IR (KBr, cm $\left.{ }^{-1}\right): 3405(\mathrm{C}-\mathrm{H}, \mathrm{N}-\mathrm{H}), 3021(\mathrm{C}-\mathrm{H}, \mathrm{Ar}-$ $\mathrm{H}), 2947\left(\mathrm{C}-\mathrm{H}, \mathrm{CH}_{2}\right), 1623(\mathrm{C}=\mathrm{N}), 1564(\mathrm{C}=\mathrm{C}), 733(\mathrm{C}-$ $\mathrm{Cl}) .{ }^{1} \mathrm{H}-\mathrm{NMR}$ (DMSO- $\left.d_{6}, \delta, \mathrm{ppm}\right): 9.97(\mathrm{H}, \mathrm{s}, \mathrm{N}-\mathrm{H})$, 7.85-6.59 (H, m, Ar-H), 8.93 (1H, s, CH, imidazole). ESI-MS $(\mathrm{m} / z)$ : $330\left(\mathbf{M}^{+}\right)$. Anal.calcd. for $\mathrm{C}_{21} \mathrm{H}_{15} \mathrm{ClN}_{2}$ : C, 76.24; H, 4.57; N, 8.47. Found: C, 76.27; H, 4.54; N, 8.37.

Synthesis of 3-(4-(biphenyl-4-yl)-1H-imidazol-2-yl) phenol (3v): Yield: $64 \%, \mathrm{Mp}: 132-133^{\circ} \mathrm{C}, \mathrm{R}_{\mathrm{f}}=0.53$. IR $\left(\mathrm{KBr}, \mathrm{cm}^{-1}\right)$ : 3451(C-H, N-H), 3267(OH), 3058(C$\mathrm{H}, \mathrm{Ar}-\mathrm{H}), 2879\left(\mathrm{C}-\mathrm{H}, \mathrm{CH}_{2}\right), 1578(\mathrm{C}=\mathrm{N}), 1551(\mathrm{C}=\mathrm{C})$. ${ }^{1} \mathrm{H}-\mathrm{NMR}$ (DMSO- $d_{6}, \delta$, ppm): $10.23(\mathrm{H}, \mathrm{s}, \mathrm{N}-\mathrm{H}), 7.95-$ $6.73(\mathrm{H}, \mathrm{m}, \mathrm{Ar}-\mathrm{H}), 8.31$ (1H, s, CH, imidazole), 9.37 $(\mathrm{H}, \mathrm{s}, \mathrm{OH})$. ESI-MS $(\mathrm{m} / \mathrm{z}): 312\left(\mathrm{M}^{+}\right)$. Anal.calcd. for $\mathrm{C}_{21} \mathrm{H}_{16} \mathrm{~N}_{2} \mathrm{O}$ : C, 64.75; H, 5.16; N, 8.97. Found: C, 60.79 ; H, 5.21; N, 8.95.

Synthesis of 4-(biphenyl-4-yl)-2-(4-chlorophenyl)1H-imidazole (3vi): Yield: $72 \%, \mathrm{Mp}$ : $185-187^{\circ} \mathrm{C}, \mathrm{R}_{\mathrm{f}}$ $=0.47$. IR $\left(\mathrm{KBr}, \mathrm{cm}^{-1}\right): 3379(\mathrm{C}-\mathrm{H}, \mathrm{N}-\mathrm{H}), 3086(\mathrm{C}-\mathrm{H}$, $\mathrm{Ar}-\mathrm{H}), 2951\left(\mathrm{C}-\mathrm{H}, \mathrm{CH}_{2}\right), 1663(\mathrm{C}=\mathrm{N}), 1491(\mathrm{C}=\mathrm{C})$, 719(C-Cl). ${ }^{1} \mathrm{H}-\mathrm{NMR}$ (DMSO-d $\left.6, \delta, \mathrm{ppm}\right): 9.73(\mathrm{H}, \mathrm{s}$, $\mathrm{N}-\mathrm{H}), \quad 7.89-6.57$ (H, m, Ar-H), 9.11(1H, s, CH, 
imidazole). ESI-MS $(\mathrm{m} / \mathrm{z}): 330\left(\mathbf{M}^{+}\right)$. Anal.calcd. for $\mathrm{C}_{21} \mathrm{H}_{15} \mathrm{ClN}_{2}$ : C, 55.30; $\mathrm{H}, 4.61 ; \mathrm{N}, 15.71$. Found: $\mathrm{C}$, $55.41 ; \mathrm{H}, 4.75 ; \mathrm{N}, 15.92$.

Synthesis of 4-(biphenyl-4-yl)-2-(4-bromophenyl)1H-imidazole (3vii): Yield: $81 \%, \mathrm{Mp}: 142-145^{\circ} \mathrm{C}, \mathrm{R}_{\mathrm{f}}$ $=0.57$. IR $\left(\mathrm{KBr}, \mathrm{cm}^{-1}\right): 3447(\mathrm{C}-\mathrm{H}, \mathrm{N}-\mathrm{H}), 3171(\mathrm{C}-\mathrm{H}$, Ar-H), $2817\left(\mathrm{C}-\mathrm{H}, \mathrm{CH}_{2}\right), 1652(\mathrm{C}=\mathrm{N}), 1539(\mathrm{C}=\mathrm{C})$, 803 (C-Br). ${ }^{1} \mathrm{H}-\mathrm{NMR}$ (DMSO- $\left.d_{6}, \delta, \mathrm{ppm}\right): 10.01(\mathrm{H}, \mathrm{s}$, $\mathrm{N}-\mathrm{H}), 7.91-6.85(\mathrm{H}, \mathrm{m}, \mathrm{Ar}-\mathrm{H}), 8.71(1 \mathrm{H}, \mathrm{s}, \mathrm{CH}$, imidazole). ESI-MS $(\mathrm{m} / \mathrm{z}): 375\left(\mathbf{M}^{+}\right)$. Anal.calcd. for $\mathrm{C}_{21} \mathrm{H}_{15} \mathrm{BrN}_{2}$ : C, 57.21; H, 4.03; N, 7.47. Found: C, $56.79 ; \mathrm{H}, 4.07$; N, 7.51.

Synthesis of 4-(biphenyl-4-yl)-2-(4-methoxyphenyl)1H-imidazole (3x): Yield: $71 \%, \mathrm{Mp}: 160-163^{\circ} \mathrm{C}, \mathrm{R}_{\mathrm{f}}=$ 0.63. IR ( $\left.\mathrm{KBr}, \mathrm{cm}^{-1}\right)$ : 3031(C-H, Ar-H), 2905(C-H, $\left.\mathrm{CH}_{2}\right), 1662(\mathrm{C}=\mathrm{N}), 1571(\mathrm{C}=\mathrm{C}) .{ }^{1} \mathrm{H}-\mathrm{NMR}$ (DMSO- $d_{6}$, $\delta$, ppm): $9.97(\mathrm{H}, \mathrm{s}, \mathrm{N}-\mathrm{H}), 7.85-6.21(\mathrm{H}, \mathrm{m}, \mathrm{Ar}-\mathrm{H}), 9.03$ $\left(1 \mathrm{H}, \mathrm{s}, \mathrm{CH}\right.$, imidazole), $3.85\left(\mathrm{H}, \mathrm{s}, \mathrm{OCH}_{3}\right)$, ESI-MS $(\mathrm{m} / \mathrm{z}): 326\left(\mathrm{M}^{+}\right)$. Anal. calcd. for $\mathrm{C}_{22} \mathrm{H}_{18} \mathrm{~N}_{2} \mathrm{O}: \mathrm{C}, 68.91$; H, 5.56; N, 8.51. Found: C, 68.79; H, 5.51; N, 8.58.

Synthesis of 3-(4-(biphenyl-4-yl)-1H-imidazol-2-yl) phenol (3xi): Yield: $78 \%$, Mp: $140-143^{\circ} \mathrm{C}, \mathrm{R}_{\mathrm{f}}=0.55$. IR $\left(\mathrm{KBr}, \mathrm{cm}^{-1}\right): 3421(\mathrm{C}-\mathrm{H}, \mathrm{N}-\mathrm{H}), 3307(\mathrm{OH}), 3041(\mathrm{C}-$ $\mathrm{H}, \mathrm{Ar}-\mathrm{H}), 2867\left(\mathrm{C}-\mathrm{H}, \mathrm{CH}_{2}\right), 1571(\mathrm{C}=\mathrm{N}), 1543(\mathrm{C}=\mathrm{C})$. ${ }^{1} \mathrm{H}-\mathrm{NMR}$ (DMSO- $d_{6}, \delta$, ppm): $10.11(\mathrm{H}, \mathrm{s}, \mathrm{N}-\mathrm{H}), 7.89-$ $6.68(\mathrm{H}, \mathrm{m}, \mathrm{Ar}-\mathrm{H}), 8.73$ (1H, s, CH, imidazole), 9.31 $(\mathrm{H}, \mathrm{s}, \mathrm{OH})$. ESI-MS $(\mathrm{m} / \mathrm{z}): 312\left(\mathrm{M}^{+}\right)$. Anal.calcd. for $\mathrm{C}_{21} \mathrm{H}_{16} \mathrm{~N}_{2} \mathrm{O}$ : C, 55.45; H, 5.19; N, 9.13. Found: C, $55.51 ; \mathrm{H}, 5.21 ; \mathrm{N}, 9.21$.

Synthesis of 4-(biphenyl-4-yl)-2-(4-fluorophenyl)1H-imidazole (3xii): Yield: $67 \%, \mathrm{Mp}: 171-175^{\circ} \mathrm{C}, \mathrm{R}_{\mathrm{f}}$ $=0.45$. IR $\left(\mathrm{KBr}, \mathrm{cm}^{-1}\right): 3127(\mathrm{C}-\mathrm{H}, \mathrm{Ar}-\mathrm{H}), 2945\left(\mathrm{CH}_{2}\right)$, 1635(C=N), 1589(C=C), $861(\mathrm{C}-\mathrm{F}) .{ }^{1} \mathrm{H}-\mathrm{NMR}$ (DMSO$\left.d_{6}, \delta, \mathrm{ppm}\right): 11.01(\mathrm{H}, \mathrm{s}, \mathrm{N}-\mathrm{H}), 8.11-7.23(\mathrm{H}, \mathrm{m}, \mathrm{Ar}-\mathrm{H})$, $9.25\left(1 \mathrm{H}, \mathrm{s}, \mathrm{CH}\right.$, imidazole). ESI-MS $(\mathrm{m} / \mathrm{z}): 314\left(\mathrm{M}^{+}\right)$. Anal.calcd. for $\mathrm{C}_{21} \mathrm{H}_{15} \mathrm{FN}_{2}$ : C, 52.35; H, 4.81; N, 8.91. Found: C, 53.21; H, 4.93; N, 8.97.

\section{Antimicrobial Evaluation}

The inhibition of microbial growth under standardized condition may be utilized for demonstrating the therapeutic efficacy of any subtle change in the antibiotic molecule. Which may not be detected by chemical method will be revealed by a reduction in the anti-microbial activity and hence microbiological assays are very useful for resolving doubts regarding possible loss of potency of antibiotics and their preparations of the antibiotic having a known activity. The in-vitro antibacterial and antifungal activities of the synthesized compounds were carried out by microdilution susceptibility test using cup-plate technique. Antibacterial activity of newly synthesized compounds (3i-xii) was screened against bacterial strains viz. Escherichia coli (E. coli, MTCC 2961), Staphylococcus aureus (S. aureus, MTCC 3160), Bacillus subtilis (B. subtilis, MTCC 121), Klebsiella pneumoniae (K. pneumoniae, MTCC 3040) and Micrococcus luteus (M. luteus, MTCC 7527). The antifungal activity was screened against fungal strains viz. Candida albicans (C. albicans, MTCC 227), Aspergillus niger (A. niger, MTCC 277) and Aspergillus flavus (A. flavus, MTCC 418). The MIC (minimum inhibitory concentration) values were determined in compare to standard drug Ciprofloxacin (anti-bacterial) and Fluconazole (anti-fungal). The MIC is considered to be the lowest drug concentration for which there is no microbial growth.

\section{Antibacterial Activity}

Experimental Procedure

In-vitro antibacterial activity of the synthesized compounds was tested by disc diffusion method under standard condition using Muller Hinton Agar medium. The test organisms were first cultured in Nutrient broth and incubated for $24 \mathrm{hrs}$ at $37^{\circ} \mathrm{C}$ and then freshly prepared bacterial cells were spread onto the Muller Hinton agar plates in a laminar flow cabinet. The test compounds which were previously dissolved in DMSO were then soaked onto sterile discs of Whatman filter paper no. 1 (6 $\mathrm{mm}$ diameter). After $24 \mathrm{hrs}$ of incubation at $37^{\circ} \mathrm{C}$, the diameter of zone of inhibition was measured for each compound in $\mathrm{mm}$. The activity was compared with standard antibiotic ciprofloxacin (positive control) and a disc impregnated with dimethylsulfoxide (DMSO) was used as a negative control $^{17,18}$. All the tests were performed in triplicate and the average was taken as final reading. Compounds which have shown good zone of inhibition were selected for minimum inhibitory concentration (MIC) determination.

\section{Antifungal activity}

\section{Experimental Procedure}

In-vitro antifungal activity of the synthesized compounds was tested by disc diffusion method under standard conditions using Potato dextrose agar medium. Sterile discs of Whatman filter paper no.1 (6 $\mathrm{mm}$ diameter) containing specific amounts of an antifungal agent fluconazole $(300 \mathrm{mg}$ for the synthesized compounds) were placed on the surface of an agar plate inoculated with a standardized suspension of the microorganisms tested. The plates were incubated at $28 \pm 2^{\circ} \mathrm{C}$ for $72 \mathrm{hrs}$ for evaluating antifungal activity. A paper disc impregnated with dimethylsulfoxide was utilized as negative control ${ }^{19,20}$. The nutrient agar medium was prepared and autoclaved at $15 \mathrm{lbs}$ pressure for 20 minutes and this media was poured into petri plates and was allowed to solidify. On the surface of media microbial suspension was spread with the help of sterilized cotton swab. Cups were made by boring into agar surface with a previously sterilized cork borer and scooping out the punched part of agar. Four cavities or cups were made in the medium and different concentrations of the test compounds and standard drug Fluconazole were poured in these cavities. The plates were kept at room temperature for $1 \mathrm{hr}$ and then incubated at $37 \pm 0.5^{\circ} \mathrm{C}$ for $24 \mathrm{hrs}$. The diameter of the zone of inhibition formed around the cavities (cups) after 24 hrs incubation was measured and percentage inhibition of the compound were evaluated. A solvent control was also run to know the activity of the blank ${ }^{21-23}$.

\section{Determination of MIC}

MIC of the compound was determined by agar streak dilution method. A stock solution of the synthesized compounds $(100 \mu \mathrm{g} / \mathrm{ml})$ in DMSO was prepared and graded quantities of the test compounds were incorporated in specified quantity of molten sterile agar (Muller Hinton agar). 
Table 1: Antibacterial activity measure by zone of inhibition of title compounds (3i-xii).

\begin{tabular}{|c|c|c|c|c|c|c|c|c|c|c|}
\hline \multirow[t]{2}{*}{ Compound } & \multicolumn{2}{|c|}{$\begin{array}{c}E \text { E. coli } \\
\text { (MTCC-1687) }\end{array}$} & \multicolumn{2}{|c|}{$\begin{array}{c}\text { S. aureus } \\
\text { (MTCC-2940) }\end{array}$} & \multicolumn{2}{|c|}{$\begin{array}{c}\text { B. subtilis } \\
\text { (MTCC- 441) }\end{array}$} & \multicolumn{2}{|c|}{$\begin{array}{c}\text { M. luteus } \\
\text { (MTCC 7527) }\end{array}$} & \multicolumn{2}{|c|}{ K. pneumonia (MTCC 3040) } \\
\hline & $\begin{array}{c}50 \\
\mu \mathrm{g} / \mathrm{mL} \pm \mathrm{SD}^{\mathrm{b}}\end{array}$ & $\begin{array}{l}100 \mu \mathrm{g} / \\
\mathrm{mL} \pm \mathrm{SD}\end{array}$ & $\begin{array}{c}50 \mu \mathrm{g} / \\
\mathrm{mL} \pm \mathrm{SD}\end{array}$ & $\begin{array}{l}100 \mu \mathrm{g} / \\
\mathrm{mL} \pm \mathrm{SD}\end{array}$ & $\begin{array}{c}50 \\
\mu \mathrm{g} / \mathrm{mL} \pm \mathrm{SD}\end{array}$ & $\begin{array}{l}100 \mu \mathrm{g} / \\
\mathrm{mL} \pm \mathrm{SD}\end{array}$ & $\begin{array}{c}50 \mu \mathrm{g} / \\
\mathrm{mL} \pm \mathrm{SD}\end{array}$ & $\begin{array}{l}100 \mu \mathrm{g} / \\
\mathrm{mL} \pm \mathrm{SD}\end{array}$ & $\begin{array}{c}50 \mu \mathrm{g} / \\
\mathrm{mL} \pm \mathrm{SD}\end{array}$ & $100 \mu \mathrm{g} / \mathrm{mL} \pm \mathrm{SD}$ \\
\hline $3 \mathrm{i}$ & $8.11 \pm 2.35$ & $14.01 \pm 2.0$ & $\mathrm{nt}$ & $\mathrm{nt}$ & $8.32 \pm 0.5$ & $9.20 \pm 1.3$ & $10.31 \pm 1.5$ & $9.31 \pm 1.1^{\prime}$ & $11.30 \pm 0.51$ & $12.31 \pm 1.15$ \\
\hline 3ii & $14.13 \pm 1.71$ & $16.78 \pm 1.2$ & $15.61 \pm 1.5$ & $17.21 \pm 2.5$ & $13.21 \pm 1.3$ & $14.21 \pm 1.3$ & $14.47 \pm 1.3$ & $17.17 \pm 1.4$ & $15.41 \pm 1.31$ & $18.51 \pm 1.37$ \\
\hline 3iii & $12.17 \pm 3.26$ & $13.58 \pm 1.2$ & $\mathrm{nt}$ & $\mathrm{nt}$ & $13.51 \pm 1.3$ & $15.72 \pm 2.3$ & $\mathrm{nt}$ & $\mathrm{nt}$ & $12.31 \pm 1.31$ & $17.31 \pm 1.13$ \\
\hline $3 i v$ & $20.31 \pm 1.51$ & $23.53 \pm 1.2$ & $14.18 \pm 1.3$ & $16.87 \pm 1.1$ & $19.17 \pm 1.1$ & $21.97 \pm 0.6$ & $15.21 \pm 1.2$ & $16.54 \pm 1.1$ & $18.13 \pm 1.15$ & $20.53 \pm 2.13$ \\
\hline $3 \mathrm{v}$ & $15.13 \pm 1.33$ & $17.37 \pm 1.0$ & $13.17 \pm 1.1$ & $14.65 \pm 1.7$ & $14.64 \pm 1.5$ & $15.61 \pm 1.12$ & $13.61 \pm 1.5$ & $15.67 \pm 0.5$ & $14.22 \pm 1.36$ & $14.61 \pm 1.13$ \\
\hline $3 \mathrm{vi}$ & $14.17 \pm 1.12$ & $16.31 \pm 1.5$ & $14.61 \pm 1.4$ & $15.23 \pm 2.5$ & $16.6 \pm 1.7$ & $15.21 \pm 1.2$ & $11.67 \pm 1.5$ & $18.31 \pm 1.1$ & $\mathrm{nt}$ & nt \\
\hline 3viii & $16.15 \pm 1.13$ & $17.36 \pm 2.3$ & $15.61 \pm 1.4$ & $16.23 \pm 2.5$ & $14.61 \pm 1.5$ & $15.31 \pm 1.1$ & $15.17 \pm 1.3$ & $17.61 \pm 0.2$ & $14.37 \pm 1.13$ & $16.89 \pm 0.55$ \\
\hline $3 i x$ & $14.15 \pm 1.11$ & $16.36 \pm 1.3$ & $15.17 \pm 1.2$ & $16.33 \pm 1.1$ & $13.23 \pm 1.1$ & $14.83 \pm 1.5$ & $15.93 \pm 1.1$ & $17.31 \pm 1.2$ & $14.31 \pm 1.13$ & $15.17 \pm 1.25$ \\
\hline $3 x$ & $18.15 \pm 1.41$ & $21.61 \pm 1.0$ & $15.11 \pm 0.5$ & $17.21 \pm 1.2$ & $17.01 \pm 1.31$ & $19.61 \pm 1.4$ & $15.16 \pm 1.5$ & $14.61 \pm 2.1$ & $17.81 \pm 1.32$ & $20.61 \pm 1.16$ \\
\hline $3 \mathrm{xi}$ & nt & nt & $13.61 \pm 1.0$ & $15.61 \pm 1.3$ & $11.51 \pm 1.7$ & $13.12 \pm 1.5$ & $9.61 \pm 1.1$ & $11.67 \pm 2.3$ & nt & nt \\
\hline 3xii & $11.68 \pm 1.15$ & $15.51 \pm 1.6$ & $11.23 \pm 2.0$ & $14.61 \pm 1.5$ & $12.33 \pm 1.3$ & $14.61 \pm 1.5$ & nt & $\mathrm{nt}$ & $15.11 \pm 1.05$ & $14.58 \pm 2.11$ \\
\hline Cipro. & $27.51 \pm 1.21$ & $29.11 \pm 1.1$ & $29.31 \pm 1.4$ & $30.37 \pm 1.7$ & $28.45 \pm 1.5$ & $29.81 \pm 1.6$ & $28.33 \pm 1.5$ & $30.17 \pm 1.1$ & $29.41 \pm 1.41$ & $30.17 \pm 1.35$ \\
\hline
\end{tabular}

Measure zone of inhibition in millimeter, SD; Standard Deviation, Compd.; Compunds, Cipro; Ciprofloxacin, nt; means not tested compounds.

Table 2: Antifungal activity as zone of inhibition of title compounds (3i-xii).

\begin{tabular}{ccccccc} 
& \multicolumn{3}{c}{ Table 2: Antifungal activity as zone of inhibition of title compounds (3i-xii). } \\
\hline Compound & \multicolumn{2}{c}{ C. albicans } & (MTCC-3617) & \multicolumn{2}{c}{ A. niger (MTCC-281) } & \multicolumn{2}{c}{ A. flavus (MTCC 418) } \\
\cline { 2 - 7 } & $50 \mu \mathrm{g} / \mathrm{mL} \pm \mathrm{SD}$ & $100 \mu \mathrm{g} / \mathrm{mL} \pm \mathrm{SD}$ & $50 \mu \mathrm{g} / \mathrm{mL} \pm \mathrm{SD}$ & $100 \mu \mathrm{g} / \mathrm{mL} \pm \mathrm{SD}$ & $50 \mu \mathrm{g} / \mathrm{mL} \pm \mathrm{SD}$ & $100 \mu \mathrm{g} / \mathrm{mL} \pm \mathrm{SD}$ \\
\hline 3i & $15.67 \pm 1.53$ & $18.31 \pm 1.54$ & $15.67 \pm 1.52$ & $19.23 \pm 1.08$ & $16.54 \pm 1.23$ & $19.13 \pm 2.01$ \\
3ii & $17.12 \pm 2.41$ & $19.63 \pm 1.21$ & $19.71 \pm 1.56$ & $20.19 \pm 1.61$ & $19.67 \pm 1.53$ & $21.81 \pm 1.64$ \\
3iii & $11.61 \pm 1.52$ & $19.17 \pm 2.26$ & $17.67 \pm 1.52$ & $16.33 \pm 1.01$ & $\mathrm{nt}$ & $\mathrm{nt}$ \\
3iv & $16.21 \pm 1.63$ & $18.73 \pm 1.08$ & $19.50 \pm 1.12$ & $22.67 \pm 1.57$ & $21.50 \pm 1.32$ & $23.61 \pm 1.53$ \\
3v & $\mathrm{nt}$ & $\mathrm{nt}$ & $16.00 \pm 1.00$ & $14.31 \pm 1.54$ & $15.03 \pm 1.42$ & $16.32 \pm 1.53$ \\
3vi & $20.61 \pm 1.04$ & $24.21 \pm 1.14$ & $21.67 \pm 1.08$ & $21.31 \pm 1.31$ & $23.67 \pm 2.08$ & $13.33 \pm 2.53$ \\
3vii & $14.67 \pm 1.63$ & $22.04 \pm 1.55$ & $13.33 \pm 1.53$ & $16.01 \pm 1.06$ & $11.33 \pm 1.33$ & $18.56 \pm 1.21$ \\
3viii & $17.31 \pm 1.34$ & $19.09 \pm 4.65$ & $14.61 \pm 1.53$ & $18.83 \pm 1.23$ & $21.67 \pm 1.51$ & $22.39 \pm 1.04$ \\
3ix & $16.67 \pm 2.51$ & $15.31 \pm 2.53$ & $16.60 \pm 1.53$ & $15.31 \pm 2.08$ & $\mathrm{nt}$ & $\mathrm{nt}$ \\
3x & $17.13 \pm 1.04$ & $19.31 \pm 1.53$ & $16.01 \pm 1.07$ & $19.36 \pm 1.53$ & $18.21 \pm 1.22$ & $20.31 \pm 1.53$ \\
3xi & $19.63 \pm 3.53$ & $22.20 \pm 1.21$ & $13.33 \pm 2.51$ & $16.43 \pm 1.12$ & $11.31 \pm 1.54$ & $17.01 \pm 1.32$ \\
3xii & $\mathrm{nt}$ & $\mathrm{nt}$ & $16.61 \pm 1.15$ & $15.81 \pm 1.04$ & $15.61 \pm 1.47$ & $16.81 \pm 1.01$ \\
Fluco. & $31.23 \pm 1.14$ & $31.81 \pm 1.72$ & $30.17 \pm 1.32$ & $31.23 \pm 1.21$ & $28.56 \pm 2.51$ & $31.15 \pm 2.13$ \\
\hline
\end{tabular}


A specified quantity of the medium $\left(40-50^{\circ} \mathrm{C}\right)$ containing the compound was poured into a Petri dish to give a depth of 3-4 $\mathrm{mm}$ and allowed to solidify. Suspension of the micro-organism was prepared to contain approximately $105 \mathrm{cfu} / \mathrm{ml}$ and applied to plates with serially diluted compounds in DMSO to be tested and incubated at 370C. At the end of the incubation period, the MIC values were determined. All determinations were done in triplicates and the average was taken as final reading. The standard antibiotic, ciprofloxacin $(100 \mu \mathrm{g} / \mathrm{ml})$ used as positive control and $100 \mathrm{~mL}$ of DMSO used as a negative control. The MIC was considered to be the lowest concentration of the test substance exhibiting no visible growth of bacteria or fungi on the plate ${ }^{24,25}$.

\section{RESULTS AND DISCUSSION \\ Chemistry}

The title compounds (3i-xii) were synthesized as per synthetic scheme outline. In this scheme biphenyl ethanone (1). Starting material) was treated with selenium dioxide to get 2-(biphenyl-4-yl)-2oxoacetaldehyde (2). Compound 2 was refluxed with different aromatic aldehydes in presence of ammonium acetate and glacial acetic acid, followed by treatment with chlorobenzene in THF to get twelve new imidazole derivatives (3i-xii). The structures of newly prepared compounds were established on the basis of modern analytical techniques (FT-IR, ${ }^{1} \mathrm{H}-\mathrm{NMR}$ and mass spectral data) and elemental analysis. The final compounds were purified by recrystalization with suitable solvent and found pure on TLC examination.

\section{Structural investigations}

The starting material 1-(biphenyl-4-yl) ethanone (biphenyl ethanone, 1) was prepared by heating biphenyl with anhydrous $\mathrm{AlCl}_{3}$ in the presence of $\mathrm{CS}_{2}$ and acetic anhydride. The usual work up of the reaction mixture followed by recrystallized from ethanol gave pure compound. The purity of the compound was verified with the help of TLC (B: A, 9:1). \% age of yield was found $83 \%$ and melting point noted 151$152^{\circ} \mathrm{C}$. IR spectra are very informative and provided evidence for the formation of expected structures. In general, IR spectra of acetophenone showed a strong band at $1673 \mathrm{~cm}^{-1}$ for the confirmation of $\mathrm{C}=\mathrm{O}$. Whereas ${ }^{1} \mathrm{H}$-NMR further confirmed the structure due to the presence of a singlet of $\mathrm{CH}_{3}$ at $2.61 \mathrm{ppm}$.

Compound 2 [2-(biphenyl-4-yl)-2-oxoacetaldehyde] was synthesized from 1-(biphenyl-4-yl) ethanone (1) in the presence of selenium dioxide and after work out of reaction gave a yellow liquid which was found pure on TLC examination (TEF 5: 4: 1). The structure of compound was confirmed on the basis of spectral studies. In IR spectra showed a band at $2851 \mathrm{~cm}^{-1}$ for the confirmation of aldehydic C-H stretching was very clear. The ${ }^{1} \mathrm{H}-\mathrm{NMR}$ spectra left no doubt with a singlet of aldehydic proton at $9.810 \mathrm{ppm}$. Compound 2 [2(biphenyl-4-yl)-2-oxoacetaldehyde] was refluxed with different aromatic aldehyde in the presence of ammonium acetate and glacial acetic acid. The usual work up of the reaction mixture followed by recrystallized from acetone to get the desired products (3i-xii). The compound was found pure on TLC examination (TEF 5: 4: 1) and its spectral data was found satisfactory for the proposed structures. The structure of this compound was confirmed on the basis of their IR and ${ }^{1} \mathrm{H}-\mathrm{NMR}$ spectral studies. In IR spectral studies, the compounds showed intense bands in the region $1535-1633 \mathrm{~cm}^{-1}$ of $\mathrm{C}=\mathrm{N}$ stretching due to the ring closure. In addition, the absorption bands at 1351$1367 \mathrm{~cm}^{-1}$ are attributed to the C-N stretching vibrations, which also confirm the formation of desired imidazole ring in the compounds. Whereas ${ }^{1} \mathrm{H}-\mathrm{NMR}$ spectra further confirm the structure due to disappearance of the peak of aldehydic proton and appearance of a single peak of $\mathrm{NH}$ (imidazole ring) at $11.23 \mathrm{ppm}$ due to ring closure.

\section{Evaluation of Anti-microbial Screening Anti-bacterial activity}

The results of anti-bacterial screening of all the newly synthesized compounds are showed in Table 2 and 3. Compound 3iv [4-(biphenyl-4-yl)-2-(3-chlorophenyl)1H-imidazole] and compound 3x [4-(biphenyl-4-yl)-2(4-methoxyphenyl)-1H-imidazole] showed notable activity against $E$. coli, B. subtilis and $K$. pneumoniae. Some of them showed moderate activity and others rest good activity. Compounds (3ii, 3viii and 3ix) were shown moderate activity against $E$. coli, $S$. aureus, $M$. luteus and $K$. pneumonia, whereas compounds (3iii, 3 vii, 3xi and 3xii) showed mild activity against few bacterial strains $\mu \mathrm{g} / \mathrm{ml}$.

\section{Anti-fungal activity}

The results of anti-fungal screening of all the newly synthesized compounds are presented in Table 4 and 5. Compound 3iv [4-(biphenyl-4-yl)-2-(3-chlorophenyl)$1 H$-imidazole] and compound 3x [4-(biphenyl-4-yl)-2(4-methoxyphenyl)-1H-imidazole] were shown notable activity against E. coli, B. subtilis and K. pneumoniae. Some of them showed moderate activity and others rest good activity. Compounds (3ii, 3viii and 3ix), showed moderate activity against $E$. coli, $S$. aureus, M. luteus and $K$. pneumonia, while compounds (3iii, 3vii, 3xi and 3xii) showed mild activity against few bacterial strains. The compounds of electron releasing imidazole derivatives (3ii, 3iv, 3viii, 3ix, 3x and xi) presented comparatively better anti-fungal activity than the compounds of electron withdrawing imidazole derivatives (3iii, 3vii and 3xii). Regarding the overall anti-fungal activity was found to be the most potent compound having meta substituted chloro group attached to the aromatic ring and methoxy group on para position.

\section{CONCLUSION}

A number of compounds 3i-xii [4-(biphenyl-4-yl)-2(substituted phenyl)- $1 H$-imidazole] have been successfully synthesized. The pharmacological study was performed to evaluate the effects of substituent on the antibacterial and antifungal activities. The biological activity result revealed that all the newly synthetic compounds 3i-xii [4-(biphenyl-4-yl)-2(substituted phenyl)- $1 \mathrm{H}$-imidazole] exhibited better antibacterial activity as compared to antifungal activity in compare to reference drug. The results of antibacterial screening further revealed that among all the compounds, the compound (3iv) and (3x) were 
observed significant anti-bacterial activity against $E$. coli, B. subtilis and $K$. pneumoniae while compounds (3ii), (3viii) and (3ix) as well as compounds (3xi) and (3vii) showed moderate anti-bacterial activity in compare to standard drug ciprofloxacin. The results of anti-fungal screening showed that the compound (3ii) and (3viii) showed good anti-fungal activity against $A$. niger and $A$. flavus and compound (3xi) showed notable activity against $C$. albicans. The compound (3vii) and (3ix) were shown moderate activity against C. albicans and A. niger.

\section{ACKNOWLEDGEMENTS}

The authors are thankful to the Dr. Sunil Kapoor, Rexin Laboratory Ltd, Baddi, Solan-173205, and Himachal Pradesh, India for valuable suggestion and guidance.

\section{AUTHOR'S CONTRIBUTION}

The manuscript was carried out, written, and approved in collaboration with all authors.

\section{CONFLICT OF INTEREST}

No conflict of interests is associated with this work.

\section{REFERENCES}

1. Ebel K, Koehler H, Gamer AO, Jackh R. Imidazole and Derivatives, In Ullmann's Encyclopedia of Industrial Chemistry; Wiley-VCH, 2002 https://doi.org/10.1002/14356007.a13 661

2. Sareen V, Gupta U, Khatri V, Chugh S. Indian J Heterocyclic Chem 2008; 17, 355.

3. Singh H, Kapoor VK. Medicinal and Pharmaceutical Chemistry, Vallabh Prakashan, Delhi, India. 2, 2008.

4. Jain AK, Ravichandran V, Sisodiya M, Agrawal RK. Synthesis and antibacterial evaluation of 2-substituted-4, 5-diphenyl-N-alkyl imidazole derivatives, Asi Pac J of Trop Med 2010; 3(6), 471-474.

https://doi.org/10.1016/S1995-7645(10)60113-7

5. Ramachandran R, Rani M, Senthan S, Jeong YT, Kabilan S. Synthesis, spectral, crystal structure and in-vitro antimicrobial evaluation of imidazole/benzotriazole substituted piperidin-4-one derivatives. Europ J Med Chem 2011; 46(5): 1926-1934.

https://doi.org/10.1016/j.ejmech.2011.02.036

6. Padmavathi V, Kumari CP, Venkatesh BC, Padmaja A, Synthesis and antimicrobial activity of amido linked pyrrolyl and pyrazolyl-oxazoles, thiazoles and imidazoles, Europ J Med Chem 2011; 46(11): 5317-5326. https://doi.org/10.1016/j.ejmech.2011.08.032

7. Wang X, Liu L, Li Y. Design, synthesis and biological evaluation of novel hybrid compounds of imidazole scaffold based 2-benzylbenzofuran as potent anticancer agents. European J Med Chem 2013; 62: 111-121. https://doi.org/10.1016/j.ejmech.2012.12.040

8. Lu X, Liu X, Wan B. Synthesis and evaluation of antitubercular and antibacterial activities of new 4-(2,6dichlorobenzyloxy)phenyl thiazole, oxazole and Imidazole derivatives. European J Med Chem 2012; 49: 164-171. https://doi.org/10.1016/j.ejmech.2012.01.007

9. Zampieri D, Mamolo MG, Laurini E, Scialino G, Banfi E, Vio L. Antifungal and antimycobacterial activity of 1-(3,5diaryl-4,5-dihydro-1H-pyrazol-4-yl)-1H-imidazole derivatives. Bioorg Med Chem 2008; 16 (8): 4516-4522. https://doi.org/10.1016/j.bmc.2008.02.055

10. Verma A, Joshi S, Singh D. Imidazole: having versatile biological activities. J Chem 2013; 45-67.

https://doi.org/10.1155/2013/329412
11. Agrawal OP. Organic chemistry reactions and reagents, Goel publishing house, New Delhi, India 2008, 627, 686.

12. Navidpour L, Shadnia H, Shafaroodi H, Amini M, Dehpour AR. Shafiee A. Bioorg Med Chem 2007; 15: 1976. https://doi.org/10.1016/j.molstruc.2020.128217

13. Schiaffella F, Macchiarulo A, Milanese L, Vecchiarelli A, Fringuelli R. Novel ketoconazole analogues based on the replacement of 2,4-dichlorophenyl group with 1,4benzothiazine moiety: design, synthesis, and microbiological evaluation. Bioorg Med Chem 2006; 14: 5196. http://dx.doi.org/10.1016/j.bmc.2006.04.004

14. Zhang P, Liu X, Zhu J, Fang Z, Li Z, Pannecouque C, Clercq ED. Synthesis and biological evaluation of imidazole thioacetanilides as novel non-nucleoside HIV-1 reverse transcriptase inhibitors. Bioorg Med Chem. 2009; 17: 5775. http://dx.doi.org/10.1016/j.bmc.2009.07.028

15. Zampieri D, Mamolo MG, Laurini E, Scialino G, Banfi E, Vio L. Antifungal and Antimycobacterial Activity of 1(3,5-diaryl-4,5-dihydro-1H-pyrazol-4-yl)-1H-imidazole Derivatives. Bioorg Med Chem 2008; 16: 4516. http://dx.doi.org/10.1016/j.bmc.2008.02.055

16. Khoshneviszadeh M, Edraki N, Javidnia K, Alborzi K, Pourabbas P, Mardaneh J, Miri R, Bioorg. Synthesis and biological evaluation of some new 1, 4-dihydropyridines containing different ester substitute and diethyl carbamoyl group as anti-tubercular agents. Med Chem 2009; 17(4): 1579-1586. https://doi.org/10.1016/j.bmc.2008.12.070

17. Kahlon DK, Lansdell TA, Fisk JS, Tepe JJ. Structuralactivity relationship study of highly-functionalized imidazolines as potent inhibitors of nuclear transcription factor-kappa B mediated IL-6 production. Bioorg Med Chem 2009; 17: 3093. https://doi.org/10.1016/j.bmc.2009.03.002

18. Singh R, Ganguly S. Synthesis, Anti-Microbial Evaluation and Structure Activity Relationship (SAR) Studies of Some 1-phenyl-3-(5-phenyl-1H-imidazol-1-yl) thiourea Derivatives. Anti-Infective Agents 2018; 16(1). https://doi.org/10.2174/2211352516666180307155830

19. Minoshima M, Chou JC, Lefebvre S, Bando T, Shinohara K, Gottesfeld JM, Sugiyama H. Potent activity against k562 cells by polyamide-seco-cbi conjugates targeting histone H4 genes. Bioorg Med Chem 2010; 18: 168-74. https://doi.org/10.1016/j.bmc.2009.11.005

20. Maruyama T,Onda K, et al. Synthesis and evaluation of novel phenylethanolamine derivatives containing acetanilides as potent and selective beta3-adrenergic receptor agonists. Chem Pharm Bulletin 2010; 58(4):533545. https://doi.org/10.1248/cpb.58.533

21. Holla BS, Malini KV, Rao BS, Sarojini BK, Kumari NS. Synthesis of some new 2,4-disubstituted thiazoles as possible antibacterial and anti-inflammatory agents. Eur $\mathbf{J}$ Med Chem. 2003; 38(3): 313-18.

https://doi.org/10.1016/s0223-5234(02)01447-2

22. Chohan ZH, Sumrra SH, Youssoufi MH, Hadda TB. Metal based biologically active compounds: design, synthesis, and antibacterial/antifungal/cytotoxic properties of triazole-derived schiff bases and their oxovanadium(iv) complexes. Eur J Med Chem. 2010; 45: 2739-47. https://doi.org/10.1016/j.ejmech.2010.02.053

23. Austel V, Martin YC, Kutter E, Austel V Eds. The medicinal chemist's approach, in modern drug research, paths to better and safer drugs. Marcel Dekker, Inc. New York. 1989; 243. https://doi.org/10.4103/0974-8520.100295

24. Hansch C, Leo A, Unger S, Kim KH, Nikaitani D, Lien E. Aromatic substituent constants for structure-activity correlations. J Med Chem.1973; 16: 1207. https://doi.org/10.1021/jm00269a003

25. Mohamed MS, Kamel MM, Kassem EMM, Abotaleb N, Abd El-moez SI, Ahmed MF. Novel 6,8-dibromo$4(3 \mathrm{H})$ quinazolinone Derivatives of Anti-Bacterial and Anti-Fungal Activities Eur J Med Chem. 45(8):3311-9. https://doi.org/10.1016/j.ejmech.2010.04.014 